\title{
Some Performance Characteristics of Subsurface Gravel Wetlands for Stormwater Management
}

\author{
James J. Houle, Ph.D., M.ASCE${ }^{1}$; and Thomas P. Ballestero, Ph.D., P.E., M.ASCE ${ }^{2}$
}

${ }^{1}$ Univ. of New Hampshire Stormwater Center, Dept. of Civil and Environmental Engineering, Durham, NH. E-mail: james.houle@unh.edu

${ }^{2}$ Univ. of New Hampshire Stormwater Center, Dept. of Civil and Environmental Engineering, Durham, NH. E-mail: tom.ballestero@unh.edu

\begin{abstract}
Subsurface gravel wetlands were originally purposed for wastewater treatment and more recently have been used for stormwater treatment as a green infrastructure technology. Systems are sized to hold the water quality volume above, and drain within 24-48 hours. Design guidance follows static sizing principles with very little hydraulic calculations, which has left a gap in hydraulic performance data. Data from 12 years of field monitoring of various systems constructed in the northeast United States is presented. These systems include fully-sized as well as undersized (hold less that the water quality volume). Hydraulics are controlled by a restrictive outlet. At the same time, this outlet also creates the wetland characteristics of the system. Pollutant removal efficiencies for common stormwater pollutants are some of the highest for green infrastructure systems, with a significant component being microbially-mediated in the low dissolved oxygen gravel layers.
\end{abstract}

\section{INTRODUCTION}

Wetlands constructed for the treatment of wastewater were introduced from Europe to the United States in the 1980's (Kadlec and Wallace, 2009). Their application for stormwater lagged however owing to the lack of understanding of stormwater as a pollutant at that time. The National Urban Runoff Program (US EPA, 1983) illustrated many of the pollutants in stormwater, and since then, stormwater treatment in other than swales and ponds greatly expanded. Much of the early implementation of wetlands for stormwater management were surface ponds retrofitted with planted benches to mimic natural wetland function. These adaptations were based on early studies that demonstrated improved water quality treatment from wet ponds and wetland system (Winer, 2000). The subsurface gravel wetland (SGW) is a new adaptation for stormwater and was first used for wastewater treatment in the 1980's (Kadlec and Wallace, 2009) and were also called: rock reed filters, vegetated submerged bed filters, and shallow horizontal bed filters. For wastewater design, specifications included (Reed, 1995):

- Originally the design required a high aspect ratio (length to width, or L:W) to ensure the maintenance of plug flow conditions and a high levels of performance (BOD removal). A common recommendation indicated that the L:W should be at least 10:1. An EPA performance study found that no penalty for aspect ratio (USEPA, 1993). What is important is plug flow.

- Hydraulic loading rates of 3-14 cm/d.

- Hydraulic residence time of 1-6 days (for BOD removal), and generally 1 to 2 days residence time is considered effective.

- Plant material might account for ten percent or less of the nitrogen- removed by the system. The majority of the nitrogen transformation (removal) is microbially mediated. 
- Media depth in most of the beds in the U.S. is about $0.6 \mathrm{~m}(2 \mathrm{ft})$, but in most cases, plant roots have been observed to penetrate only to $0.3 \mathrm{~m}(1 \mathrm{ft})$ or less.

When the systems were then employed for stormwater, much of this design guidance was directly transferred as well. The first reported use of a SGW to treat stormwater runoff was in 1987 at Lake Tahoe (Reuter, et al, 1992). The summarized results included:

- Good removals for: nitrate, iron, TSS, turbidity

- Asserted denitrification through anaerobiosis

- Nitrogen removal depended on detention time

- No flow measurements, so removal efficiency was based on mean monthly concentrations

In 1995, Egan, et al reported on a SGW in Florida designed to treat runoff from a 121-acre industrial site. Their results reported that the SGW:

- Showed great removal for sediment, fecal coliforms, and nutrients;

- Wetland vegetation had no discernible influence on pollutant removal; and

- Rock surfaces themselves were more important in pollutant removal by creating a large substrate area for growth of epilithic algae and microbes, reducing flow rates, and providing more contact surfaces.

A common early reference for the design of these systems is the Center for Watershed Protection (Claytor and Schueler, 1996). This template was the basis for the design guidance in the Georgia State Stormwater Manual in 2001, which served as the design for the first system at the University of New Hampshire Stormwater Center (UNHSC). The first UNHSC system was sized to treat runoff from one acre of asphalt parking lot. Since then, the UNHSC has developed its own SGW design guidance (latest version, 2016).

After 12 years of study at the UNHSC field site and at other monitored installations around the Northeast United States, the UNHSC has found the SGW to be one of the most highly effective stormwater management systems in practice today (UNHSC, 2007). This horizontal flow filtration system approximates the look and function of a natural wetland, while effectively removing pollutants from runoff, reducing peak stormwater flows, and enhancing the visual appeal of the landscape.

With its diverse vegetation, dense root mat, internal storage reservoir, and anaerobic microbe rich environment, this system incorporates most of the unit operations processes (UOPs) that support water quality treatment, making it an ideal testbed for design improvements to lower number of UOP systems, such as ponds or basins.

\section{SGW Design}

The SGW is designed as a series of horizontal flow-through treatment cells, preceded by a sedimentation basin (forebay) (UNHSC, 2016a, UNHSC, 2016b). The conventional primary pathway for stormwater to enter the gravel beds below is through vertical risers in each cell. A smaller amount of water may penetrate through the wetland soil to get to the gravel below, however by design the wetland soil is not very permeable in order to maintain low dissolved oxygen (DO) levels below in the gravel. The original UNHSC SGW system was designed to treat the runoff from a one-inch rainfall event (the water quality volume - WQV) and to temporarily retain 10 percent of the WQV in the forebay and 45 percent of the WQV above each treatment cell. In the gravel layer, the resident water volume is normally a little larger than $20 \%$ of the WQV. While this is the design that was originally tested, other systems have been subsequently designed and tested that have different configurations and still achieve exceptional 
water quality performance. The inclusion of a pretreatment forebay may increase maintenance activities and reduce nitrogen reduction performance if it is not well drained (UNHSC, 2010). It is recommended that if forebays cannot be economically installed to completely drain between storms then concrete inlet structures such as off-line deep sump catch basins be used for pretreatment as opposed to a forebay structure. A deep sump catch basin or other precast inlet structure may be used and may also be easier to maintain.

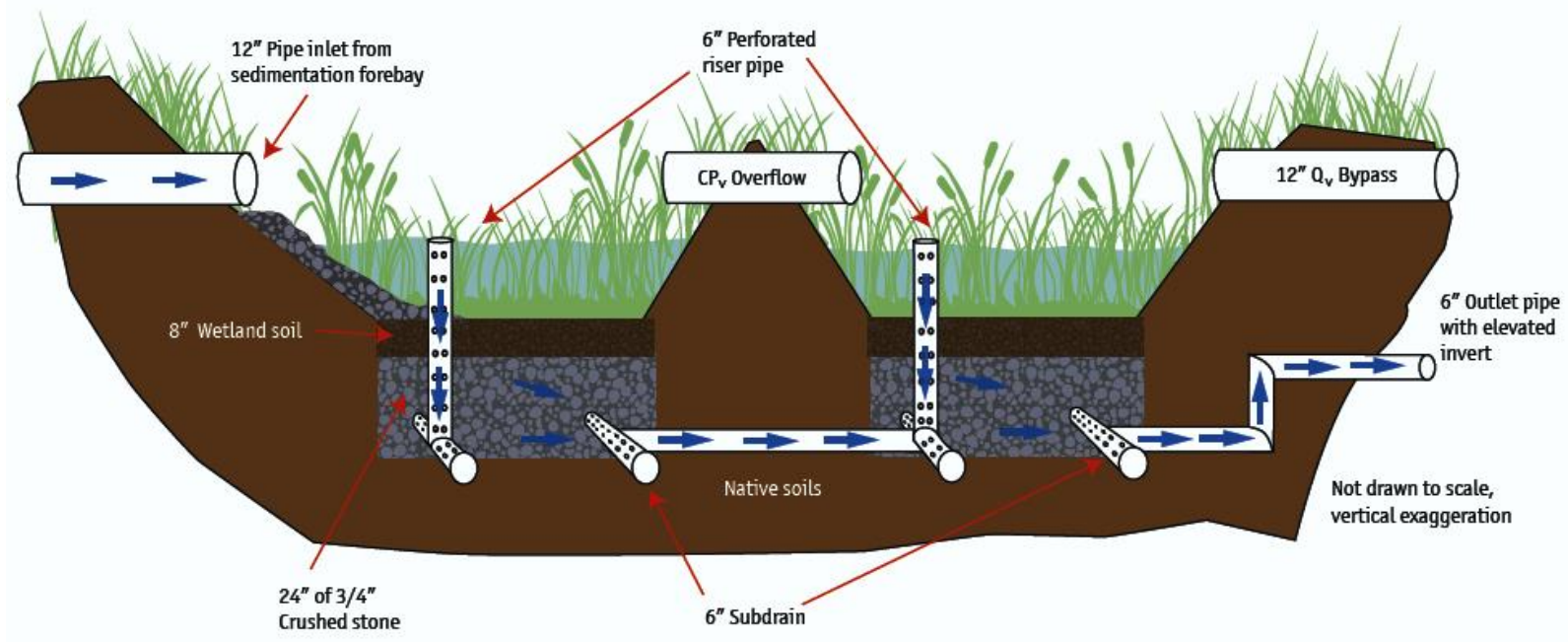

Figure 1. Cross section of typical SGW (not to scale).

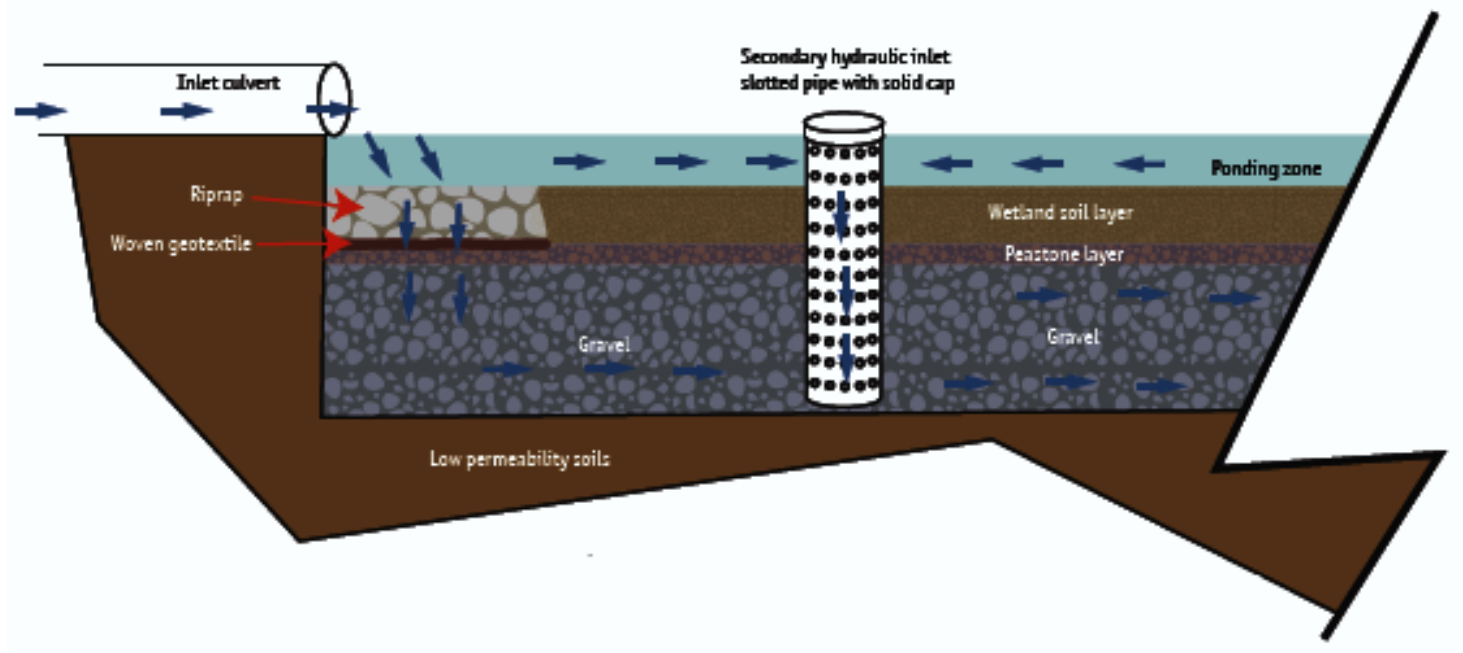

Figure 2. Alternative SGW stone inlet

The SGW is designed as an underground flow through treatment system where the stormwater travels horizontally through a saturated gravel substrate with a microbe rich environment (Figure 1). The system may be designed with a multi-staged outlet to control various flow conditions such as the Channel Protection Volume (CPV) and still allow for the overflow contingencies of larger storms. By design, the WQV is temporarily retained above the wetland soil and subsequently treated through the SGW before draining to stormwater conveyance or receiving waters. All surface basin (and forebay) side slopes should be 3:1 or flatter for maintenance. Standing water of significant depth is not expected other than during 
large rainfall events. Normally the systems are designed to drain the design stormwater volume within 24 hours. The ponding depth is controlled via the design of the high flow bypass or emergency spillway component of the system. The gravel substrate within the wetlands cells are intended to be continuously saturated below the wetland soil depth of four to eight inches (10-20 $\mathrm{cm})$. The wetland soil promotes water quality treatment conditions and supports wetland vegetation. To force the gravel layers to maintain saturation, the primary outlet from the gravel layer is inverted to be $4-8$ in $(10-20 \mathrm{~cm})$ below the wetland surface grade which is just above the top of the gravel (UNHSC, 2016a, UNHSC, 2016b).

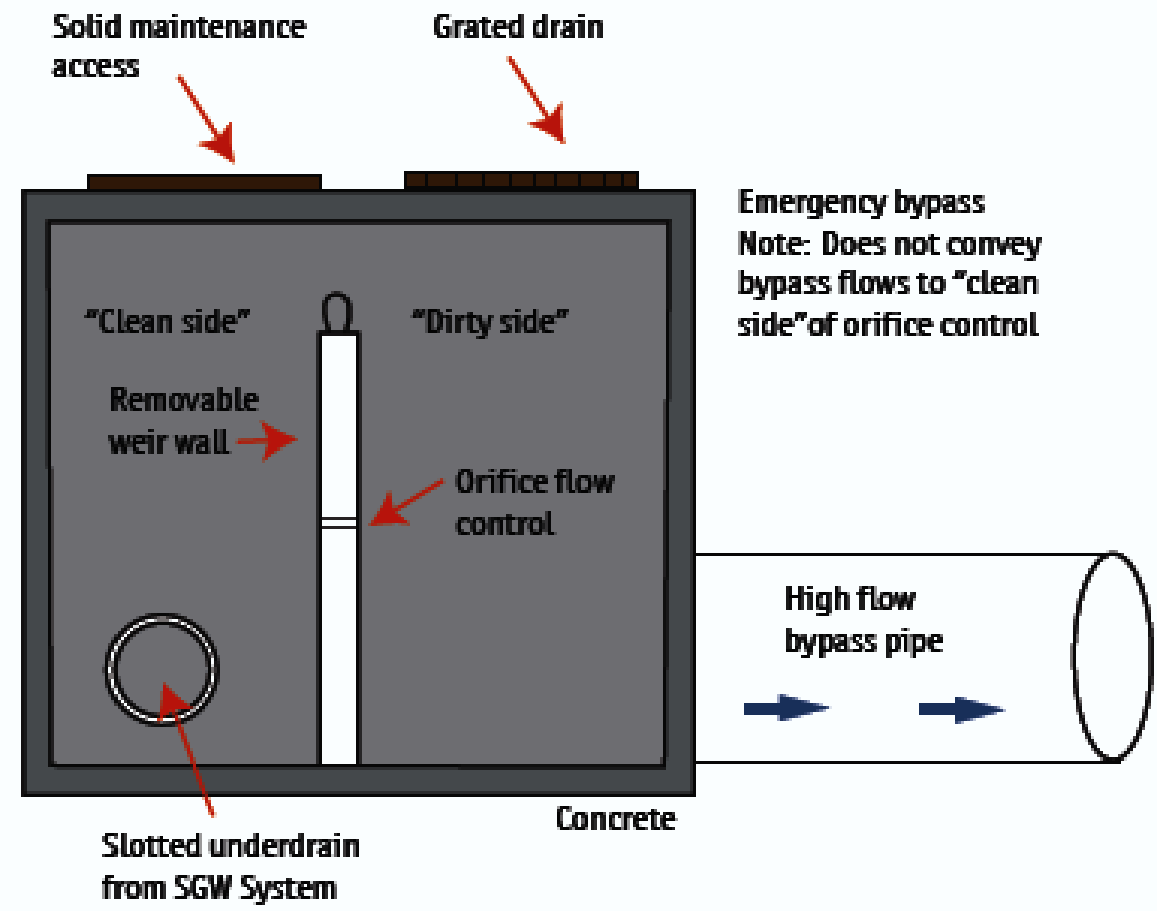

Figure 3. SGW vault outlet control structure

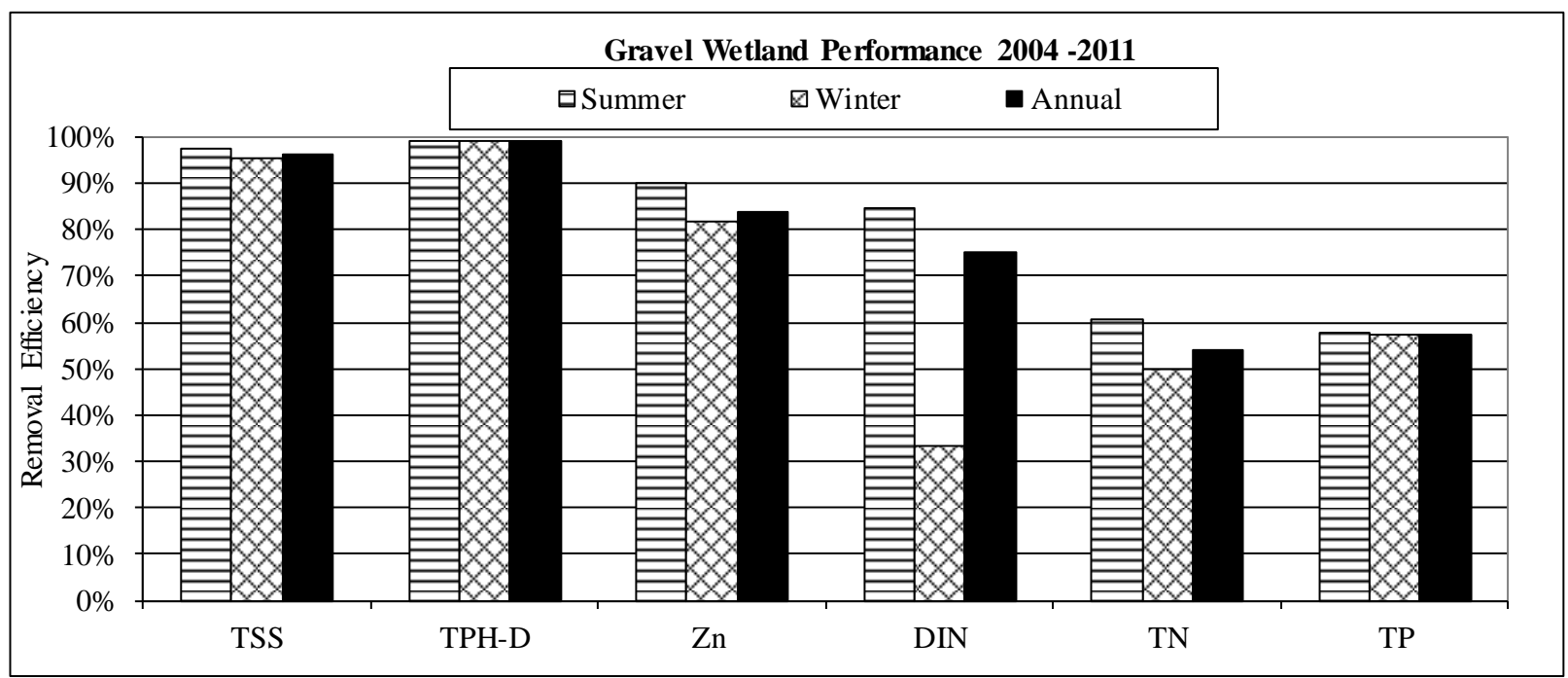

Figure 4. SGW water quality performance characteristics

Iterations of the designs tested at UNHSC are now part of the stormwater manuals for the 
states of New Hampshire, Rhode Island, New Jersey, and likely many others. UNHSC has worked directly with public agencies and private firms to install dozens of these systems throughout the Northeast, most notably along Interstates 95 and 93, New Hampshire's Route 16, and in commercial and mixed-use developments in Greenland and Durham, N.H. These installations have provided insight into how this system functions. Field testing and monitoring has allowed for design modifications and improvements over time. Most notable, are the system modifications such that it may be better adapted for popular locations for installation, such as along linear highways or in rights of way.

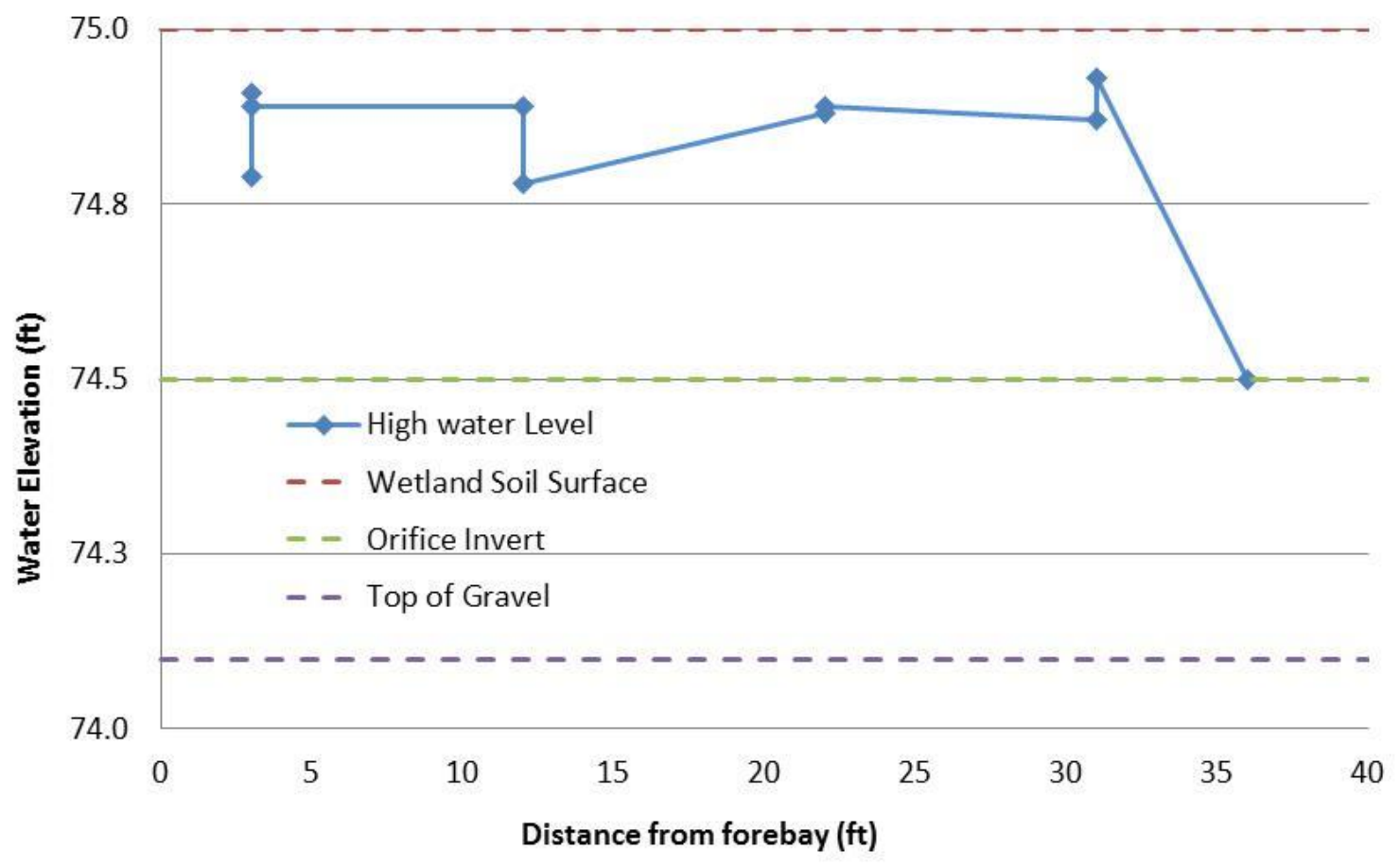

Figure 5. Hydraulic grade line through SGW stone layer wells after a 0.5 inch rainfall (25 June 2011).

UNHSC research indicates that the design of hydraulic inlet and outlet controls for subsurface gravel wetlands may be flexible. If an inlet control has a greater hydraulic capacity and efficiency than the primary outlet control, numerous configurations are possible. For example, UNHSC has tested the use of slotted hydraulic inlet pipes as backup for a primary inlet composed of woven geotextile laid on the subsurface pea stone and covered in 6- to 8-inch diameter stone around the outfall of the inlet pipe (Figure 2). This provides a more accessible and maintainable inlet at the surface, protects the stone filter, and is easier and less costly to construct.

Advances in the use of precast concrete structures have led to outlet controls that also are more maintainable and allow for multiple hydraulic controls (Figure 3). The most important design parameter is to ensure protection of the "clean" side of the low flow orifice control from any windblown or high flow conveyed debris that could clog the system and increase the need for maintenance. 


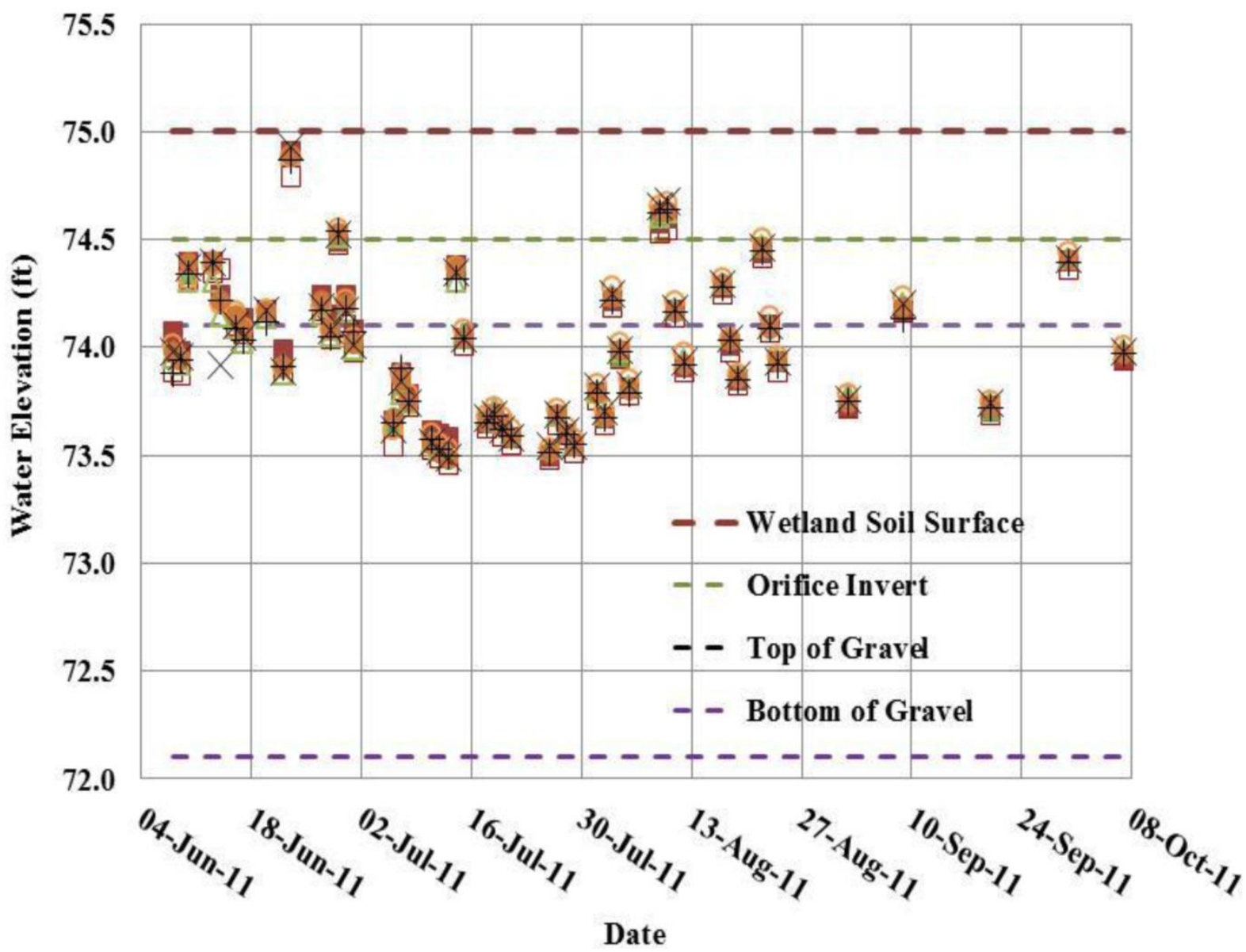

Figure 6. Water levels in SGW wells, June - October 2011. On each day, water level data was measured in wells and risers throughout the system.

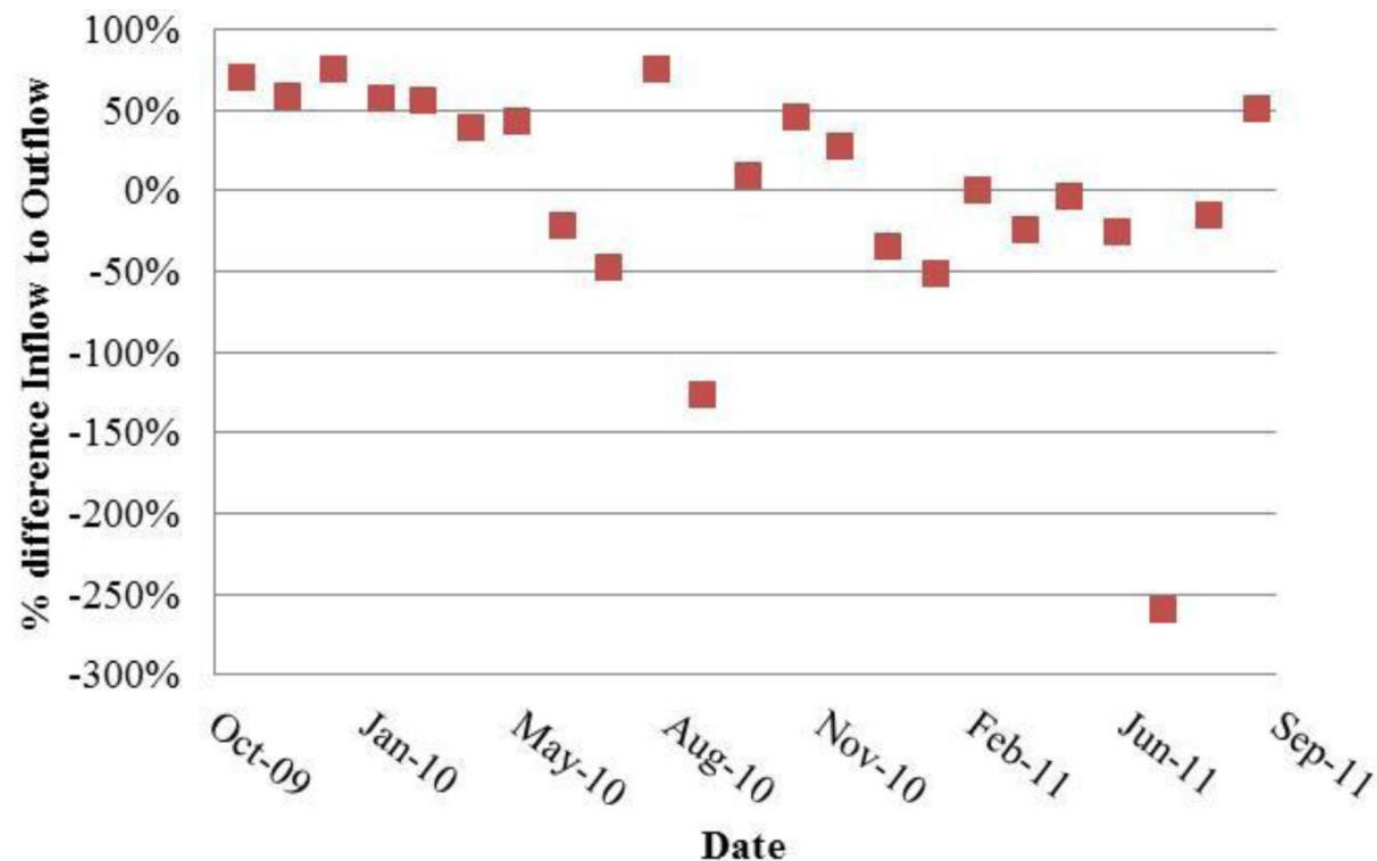

Figure 7. Water volume balance difference (inflow minus outflow divided by inflow). 

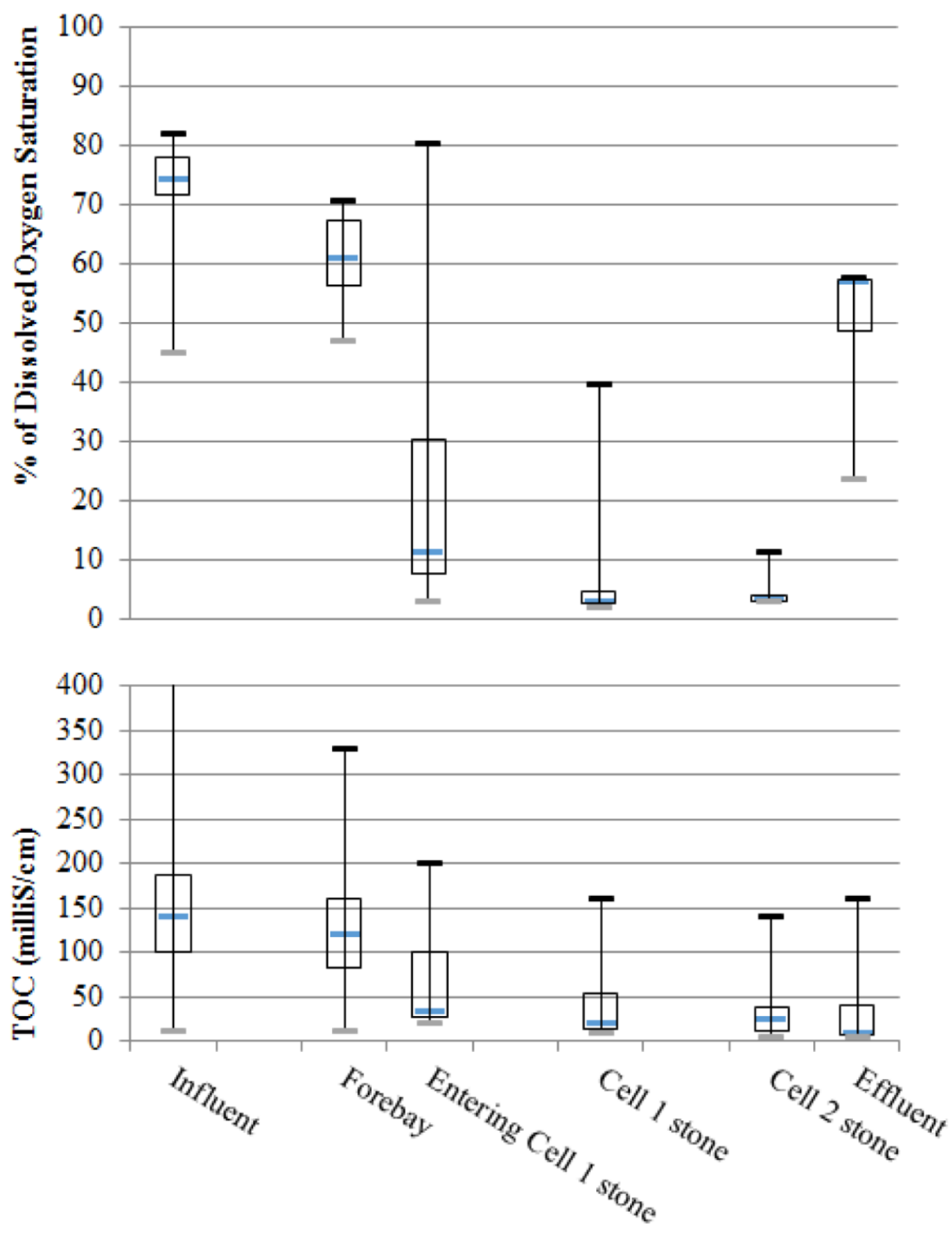

\section{Location}

Figure 8. Dissolved oxygen and total organic carbon along an SGW system

\section{Performance Data}

The SGW does an exceptional job of removing nearly all of the pollutants commonly associated with stormwater treatment performance assessments. SGWs consistently exceed USEPA's recommended level of removal for total suspended solids and meet regional ambient water quality criteria for nutrients, heavy metals, and petroleum hydrocarbons (UNHSC, 2007, Gunderson, et al, 2012). The Figure 4 reflects the SGWs performance in removing total suspended solids, dissolved inorganic nitrogen, total nitrogen, and total phosphorus. Values represent results recorded over seven years, with the data further divided into summer and winter components. This particular SGW was sized to manage the runoff from one-acre ( $0.405 \mathrm{ha})$ of 
asphalt parking lot.

The hydraulics of the SGW follow that of a simple series flow system for the primary flowpath (through gravel layer) to the primary spillway (the outlet orifice), and a parallel flow system for the secondary and emergency spillways routes. The outlet orifice is sized such that the system drains the design volume within 24 hours. All components upstream of this point (risers, gravel, distribution headers, and collection headers) have much more hydraulically efficient rating curves than the outlet orifice, and therefore for modeling purposes, storage indication routing through a SGW is exactly like that of a pond. To best exemplify the orifice control on the system hydraulics, numerous wells were installed and monitored throughout the system. Figure 5 plots the hydraulic grade line through the system when the system was partly filled after a storm of $0.5 \mathrm{in} .(12.7 \mathrm{~mm})$. Here it may be seen that the water level in the gravel is above the gravel layer but below the wetland surface. The largest and most dominant hydraulic loss is at the outlet orifice. The secondary or emergency spillways allow the SGW to be designed in line, and are sized for events larger than the design event. If the SGW can be designed in an offline configuration, that would reduce the need for the secondary and emergency spillways in the SGW design.

During very dry periods in the summer, it is not uncommon for the water level in the system to fall below the top of the gravel layer. Figure 6 depicts water levels in the system for a four month period in 2011, in which almost the entire month of July saw low water levels.

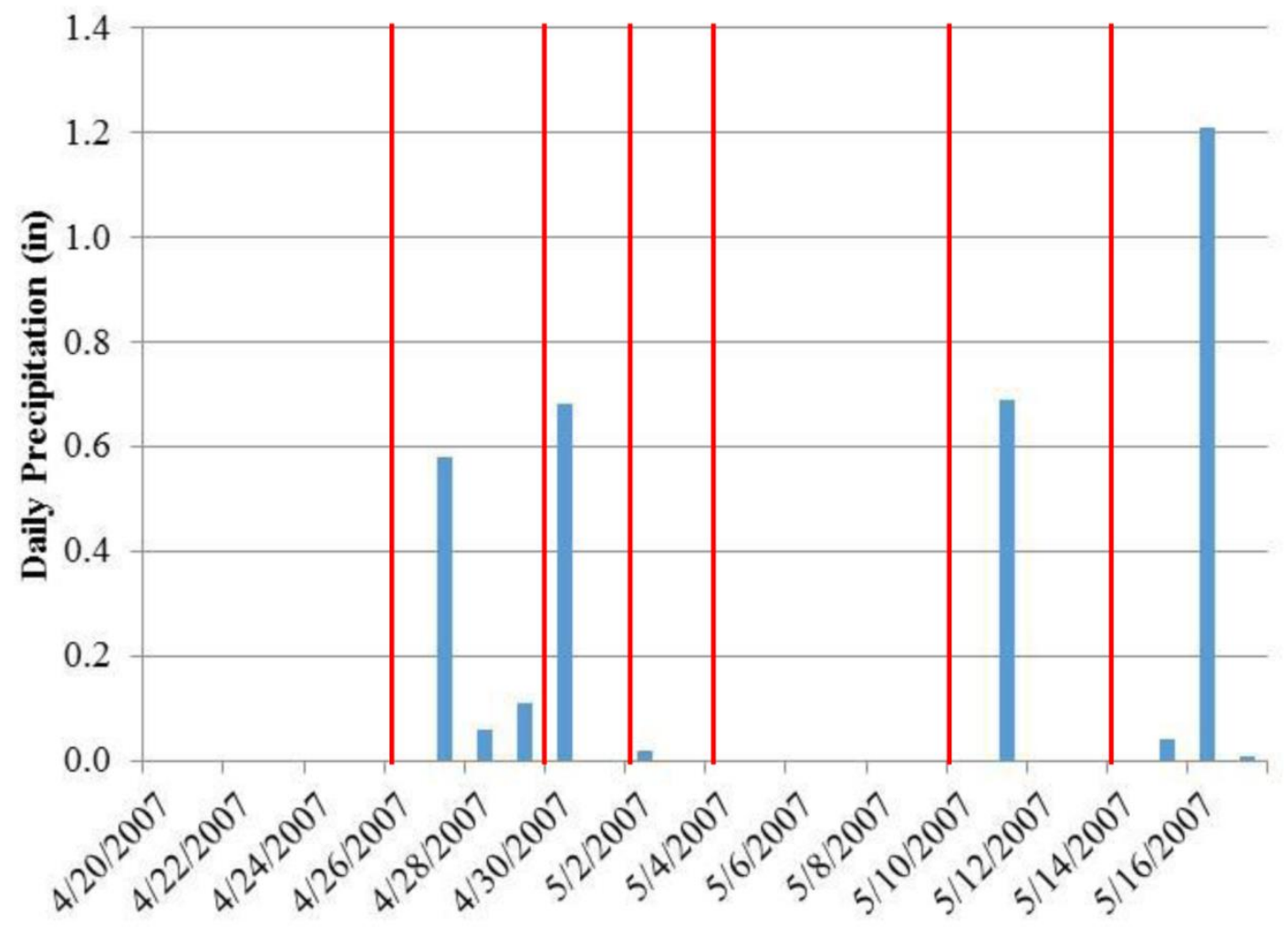

Figure 9. Precipitation history associated with Figure 8 data. Red bars are the sampling events in Figure 8.

The UNHSC constructed its very first SGW with the bottom of the gravel layer below the local groundwater table. The soils at this site are silty clay soils with very low permeability. 
While large amounts of groundwater flow may prevent the gravel layer from achieving sufficiently low dissolved oxygen levels for denitrification, the groundwater inflows at this first site did not seem to be appreciable, however they were measurable, especially in the spring each year. Flows in the UNHSC SGW were monitored on 5-minute time steps from 2004 to 2011. Figure 7 displays the monthly percent volume difference (inflow minus outflow divided by inflow) for 2009 through 2011. A positive percent difference indicates more inflow than outflow. What is not captured by this data are any flows out the secondary spillway. However the data quite clearly demonstrates that the winter and spring months dominate time periods when inflow exceeds outflow, and spring to summer months when outflow exceeds inflow, meaning groundwater inflows occur.

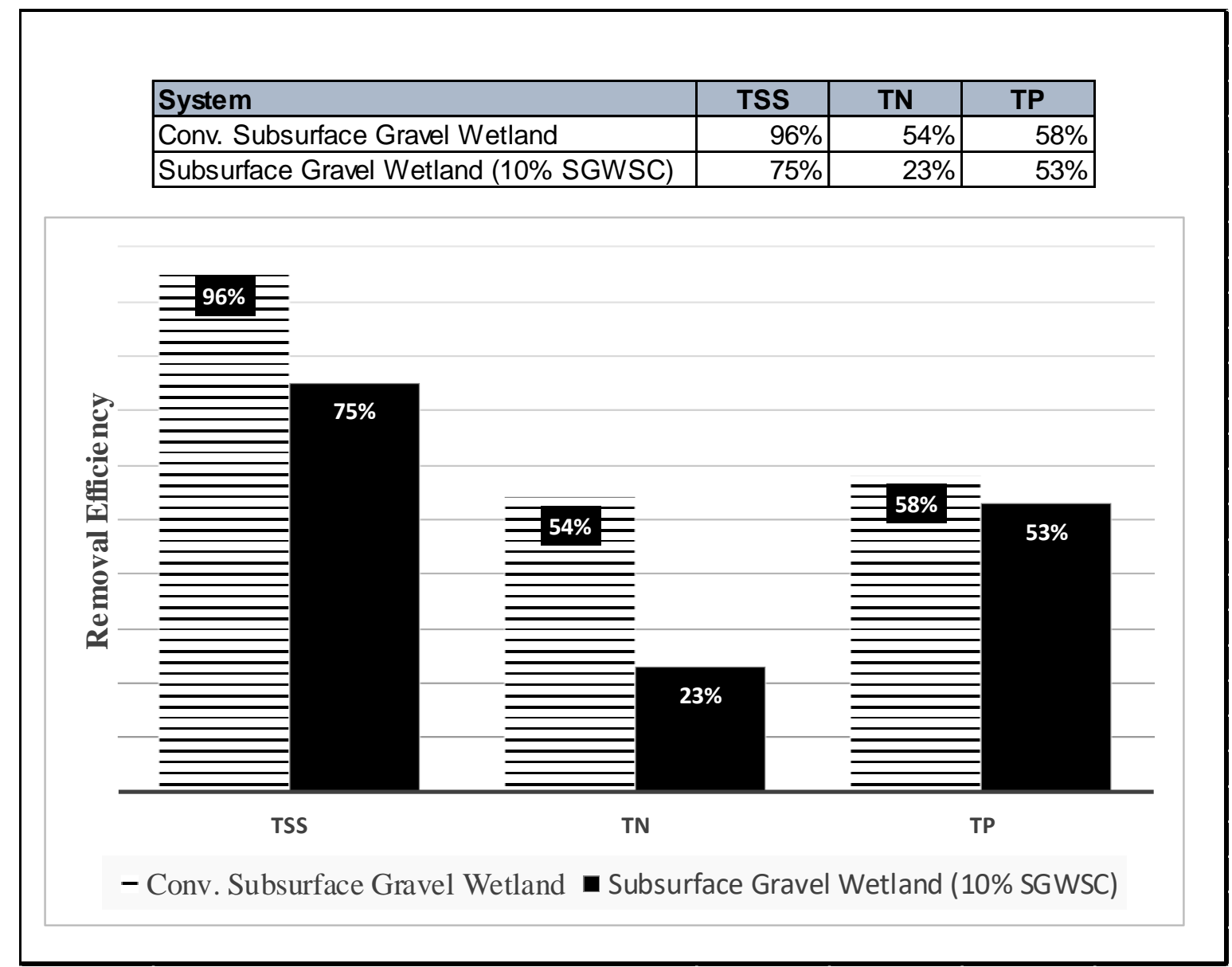

Figure 10. Pollutant removal efficiencies for a fully-sized SWQ (WQV = 1 inch $=25.4 \mathrm{~mm}$ ) versus one sized for 0.1 inch $=2.54 \mathrm{~mm}$.

In order for the SGW to denitrify, a low dissolved oxygen zone is necessary in the gravel layer. As total organic carbon (TOC) is consumed and removing oxygen in this zone, denitrifiers may then convert nitrate and nitrite to nitrogen gas. Figure 8 displays of DO and TOC data from April - May, 2007. In Figure 8, the influent, forebay, and effluent samples were all surface water samples. The water samples from the subsurface gravel layers (cell 1 and cell 2) were taken from wells located in those layers. Quite clearly, there is very low dissolved oxygen in the subsurface gravel layers, and the low DO is persistent even when new inflow water replaces the old. The wet period at the end of April, 2007 (Figure 9) pushed in sufficient new water to raise the DO in 
cell 1 but not cell 2. Because oxygenation occurs at the orifice and in the culvert leading from the orifice prior to the point of monitoring, the effluent DO is much higher than in either of the two gravel cells. Water leaving a SGW system should not cause low DO issues in receiving streams if given just a brief opportunity for oxygenation prior to discharging to receiving waters.

Many modelling and regulatory approaches only credit system pollutant removal efficiencies and subsequent pollutant load reduction for full-sized systems: systems sized for the water quality volume, which typically in the northeast United States is 1.0 to 1.5 inches (25.4 - 38.1 $\mathrm{mm}$ ). This assumption insinuates that if fully sized systems are impractical for a variety of site specific reasons then there is no value in an undersized strategy. Research at UNHSC and modeling methods used at EPA Region 1 (Tetra-Tech, 2016) underscores the benefits of opportunistic implementation, particularly for SGW systems. Fully-sized systems may be pushing many urban communities towards unnecessary costs in order to meet assumed water quality targets. In locations where fully-sized systems are too large for retrofit constraints, smaller systems still provide water quality and volume reduction benefits. As an example, Figure 10 displays the pollutant removal characteristics (TSS, TN, TP) for a fully-sized SGW and a SGW sized at only $10 \%$ of the water quality volume. In this case, the $90 \%$ reduction in WQV sizing does not translate into the same reductions in water quality performance.

\section{CONCLUSIONS}

The subsurface gravel wetland has made the transition from wastewater to stormwater. The system provides exceptional removal of common stormwater pollutants and its design is relatively straightforward without the requirement of significant modeling. Hydraulically the system is controlled at low flows by the downstream orifice. This orifice also maintains the system as a wetland as well as preserves low dissolved oxygen in the gravel layer. The primary advantage of the SGW over other green infrastructure is its nitrogen removal.

\section{REFERENCES}

Claytor, R. A., and Schueler, T. R. (1996) Design of Stormwater Filtering Systems. The Center for Watershed Protection: Silver Spring, MD.

Egan, T.J. S. Burroughs and T. Attaway (1995) "Packed Bed Filter." Proceedings of the $4^{\text {th }}$ Bienial Symposium on Stormwater Quality. Southwest Florida Water Management District. Brookeville, FL. pp.264-274.

Georgia Stormwater Management Manual, Volume 2: Technical Handbook, First Edition, August 2001, prepared by AMEC Earth and Environmental Center for Watershed Protection, Debo and Associates, Jordan Jones and Goulding, Atlanta Regional Commission.

Gunderson, Jeff, Robert M. Roseen, Thomas P. Ballestero, Alison W. Watts, James H. Houle, and Kim Farah, 2012, Subsurface Gravel Wetlands for Stormwater Management, Stormwater, Forester Communications, Nov-Dec 2012.

Kadlec, R. H., and Wallace, S. D.; Treatment Wetlands. Second edition. CRC Press, Taylor \& Francis Group. Boca Raton, FL, 2009.

Reed, Sherwood C., 1995, Natural Systems for Waste Management and Treatment / Edition 2, McGraw-Hill

Reuter, John E., Tjut Djohan, Charles R. Goldman, 1992, The use of wetlands for nutrient removal from surface runoff in a cold climate region of California-results from a newly constructed wetland at Lake Tahoe, Journal of Environmental Management, v36, Pages 3553 
Tetra Tech, 2016, Opti-Tool for Stormwater and Nutrient Management, US EPA Region 1, Boston, MA. Available at: https://www3.epa.gov/region1/npdes/stormwater/ma/opti-tooluser-guide.pdf

US EPA, 1983, Results of the Nationwide Urban Runoff Program, Volumes 1 and 2, Water Planning Division, WH-554, Washington, DC

USEPA, 1993, Subsurface Flow Constructed Wetlands for Wastewater Treatment, A Technology Assessment, Office of Water, EPA 832-R-93-008, Washington, DC.

UNHSC, 2007, University of New Hampshire Stormwater Center 2007 Annual Report, Durham, $\mathrm{NH}$.

UNHSC and NEIWPCC, 2010, Investigation of Nutrient Removal Mechanisms of a Constructed Gravel Wetland Used for Stormwater Control in a Northern Climate, Durham, NH

UNHSC, 2016a, Subsurface Gravel Wetland Design Specifications, Durham, NH. Available at: https://www.unh.edu/unhsc/sites/default/files/media/unhsc_gravel_wetland_spec_6-2016.pdf

UNHSC, 2016b, University of New Hampshire Stormwater Center 2016 Annual Report, Durham, NH.

Winer, Rebecca. 2000. National Pollutant Removal Performance Database. Center for Watershed Protection. 